\title{
Mathematical Modelling: A Study of Discrete Model of Corruption with Difference Equation Form
}

\author{
Sayaji Rastum Waykar ${ }^{[1]}$, Dr. Udaykumar H. Naik ${ }^{[2]}$ \\ Research Scholar, JJT University, Rajasthan \\ 1 C/O Assistant Professor, Department of Mathematics \\ Yashwantrao Chavan Mahavidyalaya, Halkarni Tal: Chandgad, Dist: Kolhapur, Maharashtra (India). \\ 2 Associate Professor, Department of Mathematics, Willingdon College, Sangli, Maharashtra, (India).
}

\begin{abstract}
In this paper we have to study on the problem of 'Corruption' in different ways by using mathematical modelling. Also, we have to try a study of discrete model of corruption in the difference equation form. That is the comparatively mathematical study between the discrete model of corruption in the difference equation form and mathematical corruption model in the exponential form.

The problem of corruption is everywhere, so we will try to find the solution for the problem of corruption in the society. Therefore, how to measure the corruption in the society of any field or any country in the world? So, we have found the formula that is Mathematical corruption model for measuring the corruption in the society of any field or any country of the world. When we measure the corruption in the society then there will be no difficult to remove the corruption from the society of any country in the world.
\end{abstract}

Keywords: mathematical thinking, corruption mentality, modelling, applied.

\section{Introduction}

We have to study of discrete model of corruption in the difference equation form by using Mathematical Modelling. The basic idea here is to consider systems with changes which may be thought of as occurring discretely. One example would be cells which divide synchronously and which we follow at some fixed set of times following cell division. Other examples include any organism with discrete generations e.g. many insects, plants etc. in which we follow either population size or some measure of genetic structure such as allele frequencies. The key here is that there are relatively short and synchronized actions e.g.: breeding seasons which allows one to ignore the within-time period behavior for the purpose of the Mathematical Model. An alternative view of discrete models of corruption is that they are discrete of continuous time models. That is, we cannot really observe organism continuously, so we just monitor the quantities of interest at discrete intervals. An example would be locations of individuals which move continuously, but we only observe at discrete intervals. This is the basic idea of time series analysis, which is a statistical approach to describing, predicting and controlling the behavior of a time dependent system. The appropriate formulation of Mathematical discrete model for corruption depends upon the questions:

- How much corruption exists in a given country?

- How much money is paid every year for corruption?

- What operations are more at risk of corruption?

- What amounts are paid? When and by Whom?

- What are the sectors or regions most affected by corruption?

- What are the characteristics of victims and perpetrators?

- What portion of individuals or enterprises had to pay a bribe in a given year?

- How much corruption is reported to competent authorities?

- Has the level of corruption changed over time?

- Are there certain population groups more at risk of being victim of corruption that is vulnerable groups?

We are trying to address and the appropriate temporal and spatial scale at which to focus those questions. The limitations of the available data to develop the mathematical discrete model for corruption then evaluate it. Also, the question comes in my mind that how to examine "Human Behavior, Trust and Corruption." Now we know, A general form for a first order difference equation is

$$
C_{n+1}=f\left(C_{n}\right)
$$

Where $\mathrm{C}$ denotes corruption and the function $\mathrm{f}$ determines the new value of the variable at the next time step from the previous value. This is an iteration scheme and if you know the function $\mathrm{f}$ and an initial $C_{0}$ when Mathematical E-virus Constant $K=0$ then we can just iterate the function through time to calculate successive 
values of $C_{n}$. However, the objective of mathematical analysis is to provide some general understanding of discrete models for corruption such as this, so that we can determine how the system behaves without having to iterate it numerically. Numerical iteration tells us only what one particular trajectory of the system will be through time. We had potentially had to do much iteration to get a general picture of the behavior of the system, and mathematical analysis saves us from having to do this.

\section{Methodology}

We have to use the four steps of mathematical modelling cycle for solving the problem of corruption in the society of any country of the world. The mathematical modelling process is as follows:

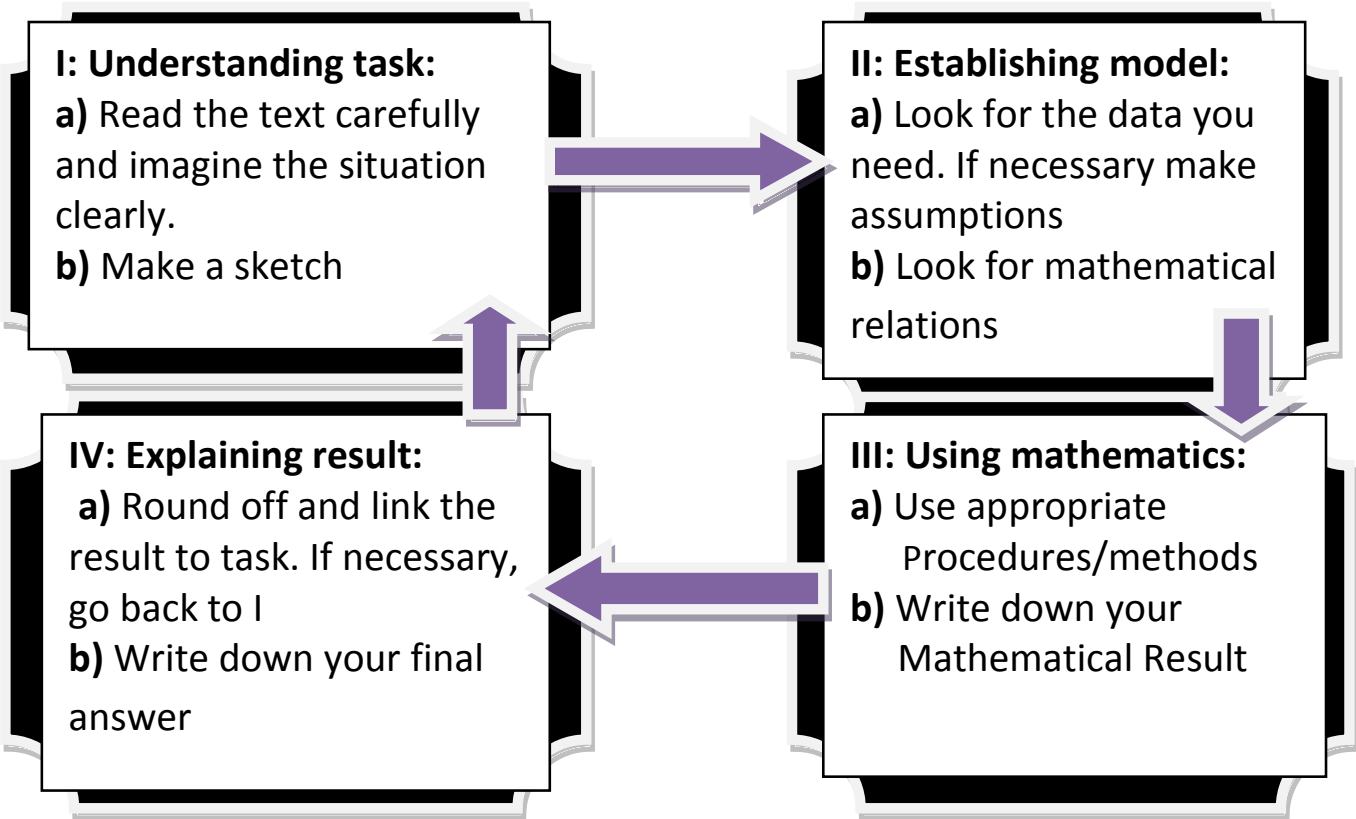

Fig.1: The "Answer Plan of a Problem" for Mathematical modeling task

A modelling task requires translations between reality and Mathematics what, in short, can be called Mathematical modelling. By reality, I mean according to Pollack (1979), the "rest of the world" outside mathematics including nature, society, everyday life and other scientific disciplines.

III. A Study of Discrete Model of Corruption with Difference Equation Form

The discrete model of corruption in the difference equation can be modeled using the formula,

$\therefore \quad \mathrm{T}=\mathrm{T}_{1}-\mathrm{T}_{2}$, where $\mathrm{T}=$ Change; $\mathrm{T}_{1}=$ Future Value; $\mathrm{T}_{2}=$ Present Value.

A dynamical system allows us to describe the change from one state of the system to the next.

At $\mathrm{n}^{\text {th }}$ stage, the change is described by

Change at stage $\mathrm{n}=$ future $(\mathrm{n}+1)^{\text {th }}$ stage - present $\mathrm{n}^{\text {th }}$ stage

$$
=C_{n+1}-C_{n}
$$

The difference $C_{n+1}-C_{n}$ is usually denoted by $\Delta C_{n}$ and is called a change or $n^{\text {th }}$ first difference. A difference equation is an equation of the form $\Delta C_{n}=f\left(C_{n}\right)$ is a discrete analogue of the autonomous differential equation $\frac{d C}{d t}=f(C)$ correspond to the accumulation points of the sequence $C_{n}$ that is the solution of difference equation $\Delta \mathrm{C}_{\mathrm{n}}=\mathrm{f}\left(\mathrm{C}_{\mathrm{n}}\right)$ with the initial value $\mathrm{C}_{0}$. Recall that the equilibrium solutions were obtained by solving $f(C)=0$ for $C$. Analogously, we obtain the limiting values by solving $f(C)=0$ for $C$. This fact can be explained also by the following argument. Note that if $\lim _{n \rightarrow \infty} C_{n}=C$, then the values of $C_{n+1}$ and of $C_{n}$ will be close to each other for large values of $n$.

Thus, $\Delta C_{n}=C_{n+1}-C_{n}=f\left(C_{n}\right)$ is close to 0 . so, when $n \rightarrow \infty, f\left(C_{n}\right) \rightarrow 0$. Thus, if $C$ is the limiting value, $\lim _{n \rightarrow \infty} C_{n}, C$ can be obtained as a solution of the equation $f(C)=0$. Let us consider a dynamical system $C_{n+1}=f\left(C_{n}\right)$. If $C$ is the limiting value, $\lim _{n \rightarrow \infty} C_{n}$, then $\lim _{n \rightarrow \infty} C_{n+1}$ is equal to $C$ as well. Thus, $C$ can obtained as a solution of the equation $C=f(C)$. Note that a limit of sequence $C_{n}$ also corresponds to the values of the sequence satisfying

$$
\mathrm{C}_{\mathrm{n}+1}=\mathrm{f}\left(\mathrm{C}_{\mathrm{n}}\right) \text { with initial value } \mathrm{C}_{0}=\mathrm{C} \text {. }
$$


Namely, if $\mathrm{C}$ is such that $\mathrm{C}=\mathrm{f}(\mathrm{C})$ and we consider a dynamical system given by $\mathrm{C}_{\mathrm{n}+1}=\mathrm{f}\left(\mathrm{C}_{\mathrm{n}}\right)$ and $\mathrm{C}_{0}=\mathrm{C}$, then $\mathrm{C}_{1}=\mathrm{f}\left(\mathrm{C}_{0}\right)=\mathrm{f}(\mathrm{C})=\mathrm{C}, \mathrm{C}_{2}=\mathrm{f}\left(\mathrm{C}_{1}\right)=\mathrm{f}(\mathrm{C})=\mathrm{C}, \ldots, \mathrm{C}_{\mathrm{n}+1}=\mathrm{f}\left(\mathrm{C}_{\mathrm{n}}\right)=\mathrm{f}(\mathrm{C})=\mathrm{C}, \ldots$.

We obtain a constant sequence with all terms equal to $C$. Because of this, the limiting value $C$ of a dynamical system $C_{n+1}=C_{n}$. Thus, $C$ is a fixed point of $C_{n+1}=f\left(C_{n}\right)$ if and only if $C=f(C)$ when $C_{0}=C$. The same terminology regarding stability is used as in the case of autonomous differential equations.

Let $\mathrm{k}$ be positive number. A frequently used dynamical system is obtained when assuming that a certain quantity is changing by a multiple of $\mathrm{k}$ in every time unit. Thus, this process can be modeled by the dynamical system $\mathrm{C}_{\mathrm{n}+1}=\mathrm{kC}_{\mathrm{n}}$ or alternatively by the difference equation $\Delta \mathrm{C}_{\mathrm{n}}=(\mathrm{k}-1) \mathrm{C}_{\mathrm{n}}$. If Mathematical Effected virus constant $\mathbf{K}$ is taken as k-1, the difference equation becomes $\Delta \mathrm{C}_{\mathrm{n}}=K \mathrm{C}_{\mathrm{n}}$ the quantity $\mathbf{K}=\mathrm{k}-1$ can be interpreted as the percent change. The equilibrium solution is obtained from equation $\mathbf{K C}=0$ and is $\mathrm{C}=0$. I distinguish the following cases:

i> If $\mathbf{K}>\mathbf{0}$, the equilibrium solution is unstable. The corruption sequences with positive initial values are increasing without bounds. It is a Positive Corruption.

ii $>$ If $\mathbf{K}=\mathbf{0}$, the corruption sequence is constant. Every term is equal to the initial value. It is a Constant Corruption.

iii $\quad$ If $\mathbf{K}<\mathbf{0}$, the equilibrium solution is stable. The corruption sequences with positive initial values are Decreasing towards 0 . It is a Negative Corruption.

It is not hard to determine the explicit formula describing the terms of the sequence.

Let $\mathrm{C}_{0}$ denote the initial value. Then $\mathrm{C}_{1}=\mathrm{kC}_{0}, \mathrm{C}_{2}=\mathrm{kC}_{1}=\mathrm{k}^{2} \mathrm{C}_{0}, \mathrm{C}_{3}=\mathrm{kC}_{2}=\mathrm{k}^{3} \mathrm{C}_{0}, \ldots \ldots \ldots$

Thus $\mathrm{C}_{\mathrm{n}}=\mathrm{k}^{\mathrm{n}} \mathrm{C}_{0}$ or $\mathrm{C}_{\mathrm{n}}=\mathrm{C}_{0}(\mathrm{~K}+\mathbf{1})^{\mathrm{n}}$.

The continuous analogue of the difference equation,

$\Delta \mathrm{C}_{\mathrm{n}}=K \mathrm{C}_{\mathrm{n}}$, with initial value $\mathrm{C}_{0}$ is the differential equation,

$$
\frac{\mathrm{dC}}{\mathrm{dt}}=K \mathrm{C}, \quad \mathrm{C}(0)=\mathrm{C}_{0} \text {. }
$$

Note that this is an autonomous differential equation with equilibrium solution $\mathrm{C}=0$ that is unstable for $\mathbf{K}>\mathbf{0}$ and stable for $\mathbf{K}<\mathbf{0}$, the differential equation $\frac{\mathrm{dC}}{\mathrm{dt}}=K C$ has solution $\mathbf{C}=\mathbf{C}_{\mathbf{0}} \mathbf{e}^{\mathrm{Kt}}$ is a Mathematical Corruption Model.

If we consider $\mathrm{n}$ as a measure of time elapsed in the discrete case, the solution

$\mathrm{C}_{\mathrm{n}}=\mathrm{C}_{0}(\mathrm{~K}+\mathbf{1})^{\mathrm{n}}$ of difference equation corresponds to the exponential function $\mathrm{C}=\mathrm{C}_{0}(\mathrm{~K}+\mathbf{1})^{\mathrm{t}}$.

Thus, if $\mathrm{C}_{0}$ is the initial size, we have that:

iv> A quantity increasing by percent $\mathbf{K}$ in discrete time intervals has the size given

$\mathrm{C}=\mathrm{C}_{0}(\mathrm{~K}+\mathbf{1})^{\mathrm{t}}$.

v> A quantity increasing by percent $\mathbf{K}$ continuously has the size given by $\mathrm{C}=\mathrm{C}_{0} \mathrm{e}^{\mathrm{Kt}}=\mathrm{C}_{0}\left(\mathrm{e}^{\mathrm{K}}\right)^{\mathrm{t}}$.

Both of the functions are exponential functions. The first one has base $1+\mathbf{K}$ and the second base $\mathbf{e}^{\mathrm{K}}$. Note that the values of $1+\mathbf{K}$ and $\mathbf{e}^{K}$ are close for small values of $\mathbf{K}$. That is $1+\mathbf{K} \approx \mathbf{e}^{\mathrm{K}}$.

Note also that $1+\mathbf{K}$ are the first two terms of the Taylor series of $\mathbf{e}^{\mathrm{K}}$ centered at zero,

$\mathbf{e}^{K}=\sum_{\mathbf{n}=\mathbf{0}}^{\infty} \frac{K^{\mathbf{n}}}{\mathbf{n} !}=\mathbf{1}+\mathbf{K}+\ldots \approx 1+\mathbf{K}$.

Therefore the discrete mathematical Corruption model is of the form, therefore

$$
\mathrm{C}=\mathrm{C}_{\mathbf{0}}(\mathrm{K}+\mathbf{1})^{\mathrm{t}}
$$

Where $\mathbf{K}=$ Mathematical E-virus Constant and $\mathbf{t}=$ Mathematical Model period. This is known as Mathematical Discrete Model of Corruption with the Difference Equation Form.

Also, we know that the Mathematical E-virus Constant with related time $\mathbf{K}$ in exponential equation form. It is of the following:

Therefore, $\mathbf{e}^{K}=\left[\frac{\mathrm{C}(\mathbf{t})}{\mathbf{C}(\mathbf{0})}\right]^{\frac{1}{\mathbf{t}}}$

But $\mathbf{e}^{K} \approx 1+\mathbf{K}$, putting in the above equation, we get

Therefore, $\quad 1+\mathbf{K}=\left[\frac{\mathbf{C}(\mathbf{t})}{\mathbf{C}(\mathbf{0})}\right]^{\frac{1}{\mathbf{t}}}$

$$
\mathbf{K}=\left[\frac{\mathbf{C}(\mathbf{t})}{\mathbf{C}(\mathbf{0})}\right]^{\frac{1}{\mathbf{t}}}-1
$$

This is known as Mathematical E-virus Constant Model with Related Time Formula in the Difference Equation Form.

Also, the another discrete model is of the form,

Therefore, $\quad \mathbf{C}=\mathbf{C}_{\mathbf{0}}(K+\mathbf{1})^{-\mathbf{t}}$ -

Where $\mathbf{K}=$ Mathematical E-virus Constant and $\mathbf{t}=$ Mathematical Model period.

This is known as Mathematical Decay of Discrete Model of Corruption with the Difference Equation Form or Mathematical Corruption Control Model (MCC Model). 
Also, we know that the Mathematical E-virus Constant $\mathbf{K}$ with related Corruption in exponential equation form. It is of the following:

$$
\begin{aligned}
& \text { Therefore, } \quad \mathrm{e}^{\mathrm{K}}=\left[\frac{\mathrm{D}(\mathrm{C})}{\mathrm{D}(0)}\right]^{\frac{1}{\mathrm{C}}-} \\
& \text { But } \mathbf{e}^{\mathrm{K}} \approx 1+\mathbf{K} \text {, putting in the equation (iii), we get }
\end{aligned}
$$$$
\text { Therefore, } 1+\mathbf{K}=\left[\frac{\mathrm{D}(\mathrm{C})}{\mathrm{D}(0)}\right]^{\frac{1}{\mathrm{C}}}
$$

$$
\mathbf{K}=\left[\frac{\mathrm{D}(\mathrm{C})}{\mathrm{D}(\mathbf{0})}\right]^{\frac{1}{\mathrm{C}}}-\mathbf{1}
$$

This is known as Mathematical E-virus Constant Model with Related Corruption Formula in the Difference Equation Form.

Also, we know that the Mathematical Corruption-Development Model in exponential equation form. It is as follows:

Therefore, $\mathbf{D}(\mathbf{C})=\mathbf{D}(\mathbf{0}) \mathbf{e}^{\mathrm{KC}}$
But $\mathbf{e}^{\mathrm{K}} \approx 1+\mathbf{K}$, putting in the equation (vi), we get

Therefore, $\quad \mathbf{D}(\mathbf{C})=\mathbf{D}(\mathbf{0})[\mathbf{1}+K]^{\mathrm{C}}$

This is known as Mathematical Corruption-Development Model with the Difference Equation Form.

We know that the Mathematical Development Model in exponential equation form. It is as follows:

Therefore, $\quad \mathrm{D}=\boldsymbol{D}_{\mathbf{0}} \mathrm{e}^{\mathrm{Kt}}$

But $\mathbf{e}^{K} \approx 1+\mathbf{K}$, putting in the equation (viii), we get

Therefore, $\quad \mathrm{D}=\boldsymbol{D}_{\mathbf{0}}[\mathbf{1}+\mathrm{K}]^{\mathrm{t}}$

This is known as Mathematical Development Model with the Difference Equation Form.

\section{Mathematical Results}

We have observed and it concluded that the Mathematical Results for finding or measuring the "Corruption" in the society. These mathematical results are as follows:

i. Mathematical Discrete Model of Corruption with the Difference Equation (or MC Model) Formula:

$$
\mathrm{C}=\mathrm{C}_{\mathbf{0}}(K+\mathbf{1})^{\mathbf{t}}
$$

ii. Mathematical Decay of Discrete Model of Corruption with the Difference Equation (or MCC Model) Formula:

$$
\mathrm{C}=\mathrm{C}_{\mathbf{0}}(\mathrm{K}+\mathbf{1})^{-\mathrm{t}}
$$

iii. Mathematical Corruption-Development Model with the Difference Equation (or MCD Model) Formula:

$$
\mathbf{D}(\mathbf{C})=\mathbf{D}(\mathbf{0})[\mathbf{1}+\mathrm{K}]^{\mathrm{C}}
$$

iv. Mathematical Development Model with the Difference Equation (or MD Model) Formula:

$$
D=D_{0}[1+K]^{t}
$$

v. Mathematical E-virus Constant Model with Related Time in the Difference Equation Formula:

$$
\mathbf{K}=\left[\frac{\mathrm{C}(\mathrm{t})}{\mathrm{C}(0)}\right]^{\frac{1}{\mathrm{t}}}-1,-1<\mathbf{K}<\mathbf{1}
$$

vi. Mathematical E-virus Constant Model with Related Corruption in the Difference Equation Formula:

$$
\mathbf{K}=\left[\frac{\mathbf{D}(\mathbf{C})}{\mathbf{D}(\mathbf{0})}\right] \overline{\mathbf{1}} \mathbf{\overline { \mathbf { C } }}-\mathbf{1},-1<\mathbf{K}<\mathbf{1}
$$

Note that if the value of $\mathbf{K}$ is more than 1 then we choose or take the value approximately to 1 but not equal to 1 . From equation (i) is a Mathematical Corruption Model and it is used for measuring the corruption in various fields of the society of any country in the world.

From equation (ii) is a Mathematical Corruption Control Model and it is used for removing or controlling corruption from the society of any country of the world.

From equation (iii) is a Mathematical Corruption-Development Model and it is used for finding the actual value of development except or related corruption in the society of any country in the world.

From equation (iv) is a Mathematical Development Model related time and it is used for finding the value of development related to a particular period. Also from equations (v) and (vi) are same that is finding the value of a Mathematical Effected Virus Constant.

\section{Some Illustrations}

5 Mathematical Corruption growths in various fields of the society (general) in India:

Suppose there was no corruption at 15 August 1947. That is $\mathrm{C}=0$ when $\mathrm{t}=0$ and $\mathrm{MEV}$ constant $\mathbf{K}=\mathbf{0}$. Now we take Mathematical model period $\mathrm{t}=10$ years. Therefore after 10 years,

5.1 Model-I: we assume that corruption was $0.25 \%$ of total population 35 crore that is 0.0875 crore on 15 August, 1957. 
Therefore at MEV constant $\mathrm{K}=0$. When $\mathrm{t}=0, \mathrm{C}(0)=C_{0}=0.0875$ crore and when $\mathrm{t}=10$ years,

$\mathrm{C}(\mathrm{t})$ depends on MEV constant. We know that MEV constant formula,

Therefore, $\mathbf{K}=\left[\frac{\mathrm{C}(\mathrm{t})}{\mathrm{C}(0)}\right]^{\frac{1}{\mathfrak{t}}}-1$

Putting in Mathematical corruption model formula (i).it is of the form,

Therefore, $\mathbf{C}=\mathbf{C}_{\mathbf{0}}(\mathbf{K}+\mathbf{1})^{\mathbf{t}}$

$$
\mathbf{C}=0.0875 \times\left[\frac{\mathrm{C}(\mathrm{t})}{\mathrm{C}(0)}\right]^{\frac{\mathrm{t}}{10}}
$$

Where $\mathbf{K}$ is known as MEV constant. So we take the various values of MEV constant $\mathbf{K}$. It is lies between 0 and 1. Such values are $0,0.20,0.40,0.60,0.80$ and 0.9988 .

Case-I: we take $\mathbf{K}=\mathbf{0}$ and $\mathbf{t}=\mathbf{1 0}$ years then from (i), $\mathrm{C}=C_{0}=\mathbf{0 . 0 8 7 5}$ crore

Therefore, $\mathbf{C}=\mathbf{0 . 0 8 7 5}$ crore

Case-II: when, we take $\mathbf{K}=\mathbf{0 . 2 0}$ and $\mathbf{t}=\mathbf{1 0}$ years, $\mathrm{C}(\mathrm{t})=\mathbf{0 . 1 0 5}$ crore then from (i),

$$
\text { Therefore, } \mathbf{C}=\mathbf{0 . 0 8 7 5} \times\left[\frac{\mathbf{0 . 1 0 5}}{\mathbf{0 . 0 8 7 5}}\right]^{\frac{\mathrm{t}}{10}}
$$

When MM period $t=10$ years from base that is 15 August 1947. What is C ?

$$
\begin{aligned}
\text { Therefore, } C & =0.0875 \times[1.20]^{\frac{10}{10}} \\
C & =0.0875 \times 1.20
\end{aligned}
$$

$$
\mathrm{C}=\mathbf{0 . 1 0 5} \text { crore }
$$

When MM period $t=20$ years from base that is 15 August 1947. What is C ?

Therefore, $\mathrm{C}=0.0875 \times[1.20]^{\frac{20}{10}}$

$$
\mathrm{C}=0.0875 \times 1.44
$$

$$
\mathrm{C}=\mathbf{0 . 1 2 6} \text { crore }
$$

When MM period $\mathrm{t}=30$ years from base that is 15 August 1947. What is C ?

Therefore, $\mathrm{C}=0.0875 \times[1.20]^{\frac{30}{10}}$

$$
\mathrm{C}=0.0875 \times 1.728
$$

$$
\mathrm{C}=\mathbf{0 . 1 5 1 2} \text { crore }
$$

When MM period $t=40$ years from base that is 15 August 1947. What is C ?

$$
\text { Therefore, } \mathrm{C}=0.0875 \times[1.20]^{\frac{40}{10}}
$$

$$
\mathrm{C}=0.0875 \times 2.0736
$$

$$
\mathrm{C}=\mathbf{0 . 1 8 1 4 4} \text { crore }
$$

When MM period $t=50$ years from base that is 15 August 1947. What is C ?

$$
\begin{aligned}
\text { Therefore, } C & =0.0875 \times[1.20]^{\frac{50}{10}} \\
C & =0.0875 \times 2.48832 \\
& C=\mathbf{0 . 2 1 7 7 2 8} \text { crore }
\end{aligned}
$$

When MM period $\mathrm{t}=60$ years from base that is 15 August 1947. What is C ?

Therefore, $\mathrm{C}=0.0875 \times[1.20]^{\frac{60}{10}}$

$$
\mathrm{C}=0.0875 \times 2.985984
$$

When MM period $t=70$ years from base that is 15 August 1947 . What is $C$ ?

Therefore, $\mathrm{C}=0.0875 \times[1.20]^{\frac{70}{10}}$

$$
\mathrm{C}=0.0875 \times 3.5831808
$$

$$
\mathrm{C}=\mathbf{0 . 3 1 3 5 2 8 3 2} \text { crore }
$$

When MM period $\mathrm{t}=80$ years from base that is 15 August 1947. What is C ?

$$
\text { Therefore, } \begin{aligned}
C & =0.0875 \times[1.20]^{\frac{80}{10}} \\
C & =0.0875 \times 4.29981696
\end{aligned}
$$

$$
\mathrm{C}=\mathbf{0 . 3 7 6 2 3 3 9 8 4} \text { crore }
$$

When MM period $\mathrm{t}=90$ years from base that is 15 August 1947. What is C ?

$$
\begin{aligned}
\text { Therefore, } \mathrm{C} & =0.0875 \times[1.20]^{\frac{90}{10}} \\
\mathrm{C} & =0.0875 \times 5.159780352
\end{aligned}
$$

$$
\mathrm{C}=\mathbf{0 . 4 5 1 4 8 0 7 8 0 8 \text { crore }}
$$

When MM period $t=100$ years from base that is 15 August 1947. What is $C$ ?

Therefore, $\mathrm{C}=0.0875 \times[1.20]^{\frac{100}{10}}$

$$
\mathrm{C}=0.0875 \times 6.1917364224
$$

$$
\mathrm{C}=\mathbf{0 . 5 4 1 7 7 6 9 3 6 9 6 \text { crore }}
$$

Case-III: when, we take $\mathbf{K}=\mathbf{0 . 4 0}$ and $\mathbf{t}=\mathbf{1 0}$ years, $\mathrm{C}(\mathrm{t}) \mathbf{= 0 . 1 2 2 5}$ crore then from (i), 
Therefore, $\mathbf{C}=\mathbf{0 . 0 8 7 5} \times\left[\frac{\mathbf{0 . 1 2 2 5}}{\mathbf{0 . 0 8 7 5}}\right]^{\mathbf{t}}$

When MM period $\mathrm{t}=10$ years from base that is 15 August 1947 . What is $\mathrm{C}$ ?

Therefore, $\mathrm{C}=0.0875 \times\left[\frac{\mathbf{0 . 1 2 2 5}}{\mathbf{0 . 0 8 7 5}}\right]^{\frac{\mathbf{1 0}}{\mathbf{1 0}}}$

$$
\mathrm{C}=0.0875 \times 1.40
$$

$$
\mathbf{C}=\mathbf{0 . 1 2 2 5} \text { crore }
$$

When MM period $\mathrm{t}=20$ years from base that is 15 August 1947 . What is $\mathrm{C}$ ?

Therefore, $\mathrm{C}=0.0875 \times\left[\frac{\mathbf{0 . 1 2 2 5}}{\mathbf{0 . 0 8 7 5}}\right]^{\frac{\mathbf{2 0}}{\mathbf{1 0}}}$

$$
\mathrm{C}=0.0875 \times 1.96
$$

$$
\mathbf{C}=\mathbf{0 . 1 7 1 5} \text { crore }
$$

When MM period $t=30$ years from base that is 15 August 1947. What is C ?

Therefore, $\mathrm{C}=0.0875 \times\left[\frac{\mathbf{0 . 1 2 2 5}}{\mathbf{0 . 0 8 7 5}}\right]^{\frac{\mathbf{3 0}}{\mathbf{1 0}}}$

$$
\mathrm{C}=0.0875 \times 2.744
$$

$$
\text { C }=0.2401 \text { crore }
$$

When MM period $t=40$ years from base that is 15 August 1947. What is C ?

Therefore, $\mathrm{C}=0.0875 \times\left[\frac{\mathbf{0 . 1 2 2 5}}{\mathbf{0 . 0 8 7 5}}\right]^{\frac{\mathbf{4 0}}{\mathbf{1 0}}}$

$$
\mathrm{C}=0.0875 \times 3.8416
$$

\section{$\mathrm{C}=\mathbf{0 . 3 3 6 1 4}$ crore}

When MM period $t=50$ years from base that is 15 August 1947 . What is $C$ ?

Therefore, $\mathrm{C}=0.0875 \times\left[\frac{\mathbf{0 . 1 2 2 5}}{\mathbf{0 . 0 8 7 5}}\right]^{\frac{\mathbf{5 0}}{\mathbf{1 0}}}$

$$
\mathrm{C}=0.0875 \times 5.37824
$$

\section{$\mathrm{C}=\mathbf{0 . 4 7 0 5 9 6}$ crore}

When MM period $t=60$ years from base that is 15 August 1947 . What is $C$ ?

Therefore, $\mathrm{C}=0.0875 \times\left[\frac{\mathbf{0 . 1 2 2 5}}{\mathbf{0 . 0 8 7 5}}\right]^{\frac{\mathbf{6 0}}{\mathbf{1 0}}}$

$$
\mathrm{C}=0.0875 \times 7.529536
$$

\section{$\mathrm{C}=\mathbf{0 . 6 5 8 8 3 4 4}$ crore}

When MM period $\mathrm{t}=70$ years from base that is 15 August 1947 . What is $\mathrm{C}$ ?

Therefore, $\mathrm{C}=0.0875 \times\left[\frac{\mathbf{0 . 1 2 2 5}}{\mathbf{0 . 0 8 7 5}}\right]^{\frac{\mathbf{7 0}}{\mathbf{1 0}}}$

$$
\mathrm{C}=0.0875 \times 10.5413504
$$

\section{$\mathrm{C}=\mathbf{0 . 9 2 2 3 6 8 1 6 \text { crore }}$}

When MM period $\mathrm{t}=80$ years from base that is 15 August 1947. What is C ?

Therefore, $\mathrm{C}=0.0875 \times\left[\frac{\mathbf{0 . 1 2 2 5}}{\mathbf{0 . 0 8 7 5}}\right]^{\mathbf{8 0}}$

$$
\mathrm{C}=0.0875 \times 14.75789056
$$

$$
\text { C }=\mathbf{1 . 2 9 1 3 1 5 4 2 4} \text { crore }
$$

When MM period $\mathrm{t}=90$ years from base that is 15 August 1947. What is C ?

Therefore, $\mathrm{C}=0.0875 \times\left[\frac{\mathbf{0 . 1 2 2 5}}{\mathbf{0 . 0 8 7 5}}\right]^{\frac{\mathbf{9 0}}{\mathbf{1 0}}}$

$$
\mathrm{C}=0.0875 \times 20.661046784
$$

\section{C $=1.8078415936$ crore}

When MM period $t=100$ years from base that is 15 August 1947 . What is $C$ ?

Therefore, $\mathrm{C}=0.0875 \times\left[\frac{\mathbf{0 . 1 2 2 5}}{\mathbf{0 . 0 8 7 5}}\right]^{\frac{\mathbf{1 0 0}}{\mathbf{1 0}}}$

$$
\mathrm{C}=0.0875 \times 28.9254654976
$$

$$
\mathrm{C}=\mathbf{2 . 5 3 0 9 7 8 2 3 1 0 4 \text { crore }}
$$

Case-IV: when, we take $\mathbf{K}=\mathbf{0 . 6 0}$ and $\mathbf{t}=\mathbf{1 0}$ years, $\mathrm{C}(\mathrm{t})=\mathbf{0 . 1 4}$ crore then from (i),

$$
\text { Therefore, } \mathbf{C}=\mathbf{0 . 0 8 7 5} \times\left[\frac{0.14}{\mathbf{0 . 0 8 7 5}}\right]^{\frac{\mathrm{t}}{10}}
$$

When MM period $t=10$ years from base that is 15 August 1947 . What is $C$ ?

Therefore, $\mathrm{C}=0.0875 \times\left[\frac{\mathbf{0 . 1 4}}{\mathbf{0 . 0 8 7 5}}\right]^{\frac{\mathbf{1 0}}{\mathbf{1 0}}}$

$$
\mathrm{C}=0.0875 \times 1.60
$$

$$
\mathrm{C}=\mathbf{0 . 1 4} \text { crore }
$$

When MM period $t=20$ years from base that is 15 August 1947 . What is C ?

Therefore, $\mathrm{C}=0.0875 \times\left[\frac{\mathbf{0 . 1 4}}{\mathbf{0 . 0 8 7 5}}\right]^{\frac{\mathbf{2 0}}{10}}$

$$
\mathrm{C}=0.0875 \times 2.56
$$




$$
\mathrm{C}=\mathbf{0 . 2 2 4} \text { crore }
$$

When MM period $\mathrm{t}=30$ years from base that is 15 August 1947. What is $\mathrm{C}$ ?

Therefore, $\mathrm{C}=0.0875 \times\left[\frac{\mathbf{0 . 1 4}}{\mathbf{0 . 0 8 7 5}}\right]^{\frac{\mathbf{3 0}}{\mathbf{1 0}}}$

$$
\mathrm{C}=0.0875 \times 4.096
$$

$$
\mathrm{C}=\mathbf{0 . 3 5 8 4} \text { crore }
$$

When MM period $t=40$ years from base that is 15 August 1947 . What is $C$ ?

Therefore, $\mathrm{C}=0.0875 \times\left[\frac{\mathbf{0 . 1 4}}{\mathbf{0 . 0 8 7 5}}\right]^{\frac{\mathbf{4 0}}{\mathbf{1 0}}}$

$$
\mathrm{C}=0.0875 \times 10.48576
$$

$$
\mathrm{C}=\mathbf{0 . 9 1 7 5 0 4} \text { crore }
$$

When MM period $t=50$ years from base that is 15 August 1947 . What is C ?

Therefore, $\mathrm{C}=0.0875 \times\left[\frac{\mathbf{0 . 1 4}}{\mathbf{0 . 0 8 7 5}}\right]^{\frac{\mathbf{5 0}}{\mathbf{1 0}}}$

$$
\mathrm{C}=0.0875 \times 16.777216
$$

\section{$\mathrm{C}=\mathbf{1 . 4 6 8 0 0 6 4}$ crore}

When MM period $\mathrm{t}=60$ years from base that is 15 August 1947. What is $\mathrm{C} ?$

Therefore, $\mathrm{C}=0.0875 \times\left[\frac{\mathbf{0 . 1 4}}{\mathbf{0 . 0 8 7 5}}\right]^{\frac{\mathbf{6 0}}{\mathbf{1 0}}}$

$$
\mathrm{C}=0.0875 \times 26.8435456
$$

$$
\mathrm{C}=\mathbf{2 . 3 4 8 8 1 0 2 4} \text { crore }
$$

When MM period $\mathrm{t}=70$ years from base that is 15 August 1947 . What is C ?

Therefore, $\mathrm{C}=0.0875 \times\left[\frac{\mathbf{0 . 1 4}}{\mathbf{0 . 0 8 7 5}}\right]^{\frac{\mathbf{7 0}}{\mathbf{1 0}}}$

$$
\mathrm{C}=0.0875 \times 42.94967296
$$

$$
\mathrm{C}=\mathbf{3 . 7 5 8 0 9 6 3 8 4} \text { crore }
$$

When MM period $\mathrm{t}=80$ years from base that is 15 August 1947 . What is $\mathrm{C}$ ?

Therefore, $\mathrm{C}=0.0875 \times\left[\frac{\mathbf{0 . 1 4}}{\mathbf{0 . 0 8 7 5}}\right]^{\frac{\mathbf{8 0}}{\mathbf{1 0}}}$

$$
\mathrm{C}=0.0875 \times 68.719476736
$$

$$
\mathrm{C}=\mathbf{6 . 0 1 2 9 5 4 2 1 4 4} \text { crore }
$$

When MM period $\mathrm{t}=90$ years from base that is 15 August 1947. What is C ?

Therefore, $\mathrm{C}=0.0875 \times\left[\frac{\mathbf{0 . 1 4}}{\mathbf{0 . 0 8 7 5}}\right]^{\frac{90}{10}}$

$$
\mathrm{C}=0.0875 \times 109.9511627776
$$

$$
\text { C }=9.62072674304 \text { crore }
$$

When MM period $\mathrm{t}=100$ years from base that is 15 August 1947. What is C ?

Therefore, $\mathrm{C}=0.0875 \times\left[\frac{\mathbf{0 . 1 4}}{\mathbf{0 . 0 8 7 5}}\right]^{\mathbf{1 0 0}}$

$$
\mathrm{C}=0.0875 \times 175.92186044416
$$

$$
\mathrm{C}=\mathbf{1 5 . 3 9 3 1 6 2 7 8 8 8 6 4 \text { crore }}
$$

Case-V: when, we take $\mathbf{K}=\mathbf{0 . 8 0}$ and $\mathbf{t}=\mathbf{1 0}$ years, $\mathrm{C}(\mathrm{t})=\mathbf{0 . 1 5 7 5}$ crore then from $(\mathrm{i})$,

Therefore, $\mathbf{C}=\mathbf{0 . 0 8 7 5} \times\left[\frac{\mathbf{0 . 1 5 7 5}}{\mathbf{0 . 0 8 7 5}}\right]^{\frac{\mathrm{t}}{10}}$

When MM period $t=10$ years from base that is 15 August 1947. What is C ?

Therefore, $\mathrm{C}=0.0875 \times\left[\frac{\mathbf{0 . 1 5 7 5}}{\mathbf{0 . 0 8 7 5}}\right]^{\frac{\mathbf{1 0}}{\mathbf{1 0}}}$

$$
\mathrm{C}=0.0875 \times 1.80
$$

$$
\mathrm{C}=\mathbf{0 . 1 5 7 5} \text { crore }
$$

When MM period $\mathrm{t}=20$ years from base that is 15 August 1947 . What is C ?

Therefore, $\mathrm{C}=0.0875 \times\left[\frac{\mathbf{0 . 1 5 7 5}}{\mathbf{0 . 0 8 7 5}}\right]^{\frac{\mathbf{2 0}}{\mathbf{1 0}}}$

$$
\mathrm{C}=0.0875 \times 3.24
$$

$$
\mathrm{C}=\mathbf{0 . 2 8 3 5} \text { crore }
$$

When MM period $t=30$ years from base that is 15 August 1947. What is C ?

Therefore, $\mathrm{C}=0.0875 \times\left[\frac{\mathbf{0 . 1 5 7 5}}{\mathbf{0 . 0 8 7 5}}\right]^{\frac{\mathbf{3 0}}{\mathbf{1 0}}}$

$$
\mathrm{C}=0.0875 \times 5.832
$$

$$
\mathrm{C}=\mathbf{0 . 5 1 0 3} \text { crore }
$$

When MM period $t=40$ years from base that is 15 August 1947 . What is $C$ ?

Therefore, $\mathrm{C}=0.0875 \times\left[\frac{\mathbf{0 . 1 5 7 5}}{\mathbf{0 . 0 8 7 5}}\right]^{\frac{\mathbf{4 0}}{\mathbf{1 0}}}$

$$
\mathrm{C}=0.0875 \times 10.4976
$$




\section{$\mathrm{C}=\mathbf{0 . 9 1 8 5 4}$ crore}

When MM period $\mathrm{t}=50$ years from base that is 15 August 1947. What is $\mathrm{C}$ ?

Therefore, $\mathrm{C}=0.0875 \times\left[\frac{\mathbf{0 . 1 5 7 5}}{\mathbf{0 . 0 8 7 5}}\right]^{\frac{50}{10}}$

$$
\mathrm{C}=0.0875 \times 18.89568
$$

$$
\mathrm{C}=\mathbf{1 . 6 5 3 3 7 2} \text { crore }
$$

When MM period $t=60$ years from base that is 15 August 1947. What is C ?

Therefore, $C=0.0875 \times\left[\frac{\mathbf{0 . 1 5 7 5}}{\mathbf{0 . 0 8 7 5}}\right]^{\mathbf{6 0}}$

$$
\mathrm{C}=0.0875 \times 30.233088
$$

$$
\mathrm{C}=\mathbf{2 . 6 4 5 3 9 5 2} \text { crore }
$$

When MM period $\mathrm{t}=70$ years from base that is 15 August 1947. What is C ?

Therefore, $\mathrm{C}=0.0875 \times\left[\frac{\mathbf{0 . 1 5 7 5}}{\mathbf{0 . 0 8 7 5}}\right]^{\mathbf{7 0}}$

$$
\mathrm{C}=0.0875 \times 54.4195584
$$

$$
\mathrm{C}=\mathbf{4 . 7 6 1 7 1 1 3 6 \text { crore }}
$$

When MM period $\mathrm{t}=80$ years from base that is 15 August 1947. What is C ?

Therefore, $C=0.0875 \times\left[\frac{\mathbf{0 . 1 5 7 5}}{\mathbf{0 . 0 8 7 5}}\right]^{\frac{80}{10}}$

$$
\mathrm{C}=0.0875 \times 97.95520512
$$

$$
C=8.571080448 \text { crore }
$$

When MM period $\mathrm{t}=90$ years from base that is 15 August 1947. What is C ?

Therefore, $\mathrm{C}=0.0875 \times\left[\frac{\mathbf{0 . 1 5 7 5}}{\mathbf{0 . 0 8 7 5}}\right]^{\mathbf{9 0}}$

$$
\mathrm{C}=0.0875 \times 176.319369216
$$

$$
C=15.4279448064 \text { crore }
$$

When MM period $t=100$ years from base that is 15 August 1947. What is C ?

Therefore, $\mathrm{C}=0.0875 \times\left[\frac{\mathbf{0 . 1 5 7 5}}{\mathbf{0 . 0 8 7 5}}\right]^{\mathbf{1 0 0}}$

$$
\mathrm{C}=0.0875 \times 317.3748645888
$$

$$
C=27.77030065152 \text { crore }
$$

Case-VI: when, we take $\mathrm{K}=\mathbf{0 . 9 9 8 8}$ and $\mathrm{t}=\mathbf{1 0}$ years, $\mathrm{C}(\mathrm{t})=\mathbf{0 . 1 7 4 8 9 5}$ crore then from $(\mathrm{i})$,

Therefore, $\mathrm{C}=\mathbf{0 . 0 8 7 5} \times\left[\frac{0.174895}{0.0875}\right]^{\frac{\mathrm{t}}{\mathbf{1 0}}}$

When MM period $t=10$ years from base that is 15 August 1947 . What is C ?

Therefore, $\mathrm{C}=0.0875 \times\left[\frac{\mathbf{0 . 1 7 4 8 9 5}}{\mathbf{0 . 0 8 7 5}}\right]^{\frac{\mathbf{1 0}}{\mathbf{1 0}}}$

$$
\mathrm{C}=0.0875 \times 1.9988
$$

$$
C=0.174895 \text { crore }
$$

When MM period $t=20$ years from base that is 15 August 1947 . What is $C$ ?

Therefore, $C=0.0875 \times\left[\frac{\mathbf{0 . 1 7 4 8 9 5}}{\mathbf{0 . 0 8 7 5}}\right]^{\frac{20}{10}}$

$$
C=0.0875 \times 3.99520144
$$

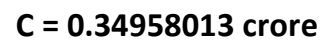

When MM period $t=30$ years from base that is 15 August 1947. What is $C$ ?

Therefore, $C=0.0875 \times\left[\frac{\mathbf{0 . 1 7 4 8 9 5}}{\mathbf{0 . 0 8 7 5}}\right]^{\frac{30}{\mathbf{1 0}}}$

$$
C=0.0875 \times 7.98560864
$$

$$
\mathrm{C}=\mathbf{0 . 6 9 8 7 4 0 7 6 \text { crore }}
$$

When MM period $t=40$ years from base that is 15 August 1947 . What is $C$ ?

Therefore, $C=0.0875 \times\left[\frac{\mathbf{0 . 1 7 4 8 9 5}}{\mathbf{0 . 0 8 7 5}}\right]^{\frac{40}{10}}$

$$
C=0.0875 \times 15.9616345
$$

\section{$\mathrm{C}=\mathbf{1 . 3 9 6 6 4 3 0 2 \text { crore }}$}

When MM period $t=50$ years from base that is 15 August 1947. What is $C$ ?

Therefore, $C=0.0875 \times\left[\frac{\mathbf{0 . 1 7 4 8 9 5}}{\mathbf{0 . 0 8 7 5}}\right]^{\frac{50}{10}}$

$$
C=0.0875 \times 31.904115
$$

\section{C $=\mathbf{2 . 7 9 1 6 1 0 0 6}$ crore}

When MM period $t=60$ years from base that is 15 August 1947 . What is $C$ ?

Therefore, $C=0.0875 \times\left[\frac{0.174895}{0.0875}\right]^{\frac{60}{10}}$ 


$$
C=0.0875 \times 63.7699451
$$

\section{C $=\mathbf{5 . 5 7 9 8 7 0 2}$ crore}

When MM period $t=70$ years from base that is 15 August 1947 . What is $C$ ?

Therefore, $C=0.0875 \times\left[\frac{\mathbf{0 . 1 7 4 8 9 5}}{\mathbf{0 . 0 8 7 5}}\right]^{\frac{70}{\mathbf{1 0}}}$

$$
C=0.0875 \times 127.463366
$$

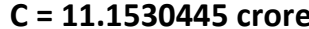

When MM period $t=80$ years from base that is 15 August 1947. What is $C$ ?

Therefore, $C=0.0875 \times\left[\frac{\mathbf{0 . 1 7 4 8 9 5}}{\mathbf{0 . 0 8 7 5}}\right]^{\frac{80}{10}}$

$$
\mathrm{C}=0.0875 \times 254.773776
$$

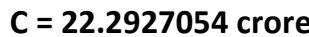

When MM period $t=90$ years from base that is 15 August 1947. What is $C$ ?

Therefore, $C=0.0875 \times\left[\frac{\mathbf{0 . 1 7 4 8 9 5}}{\mathbf{0 . 0 8 7 5}}\right]^{\mathbf{9 0}}$

$$
C=0.0875 \times 509.241823
$$

\section{C $=\mathbf{4 4 . 5 5 8 6 5 9 5}$ crore}

When MM period $t=100$ years from base that is 15 August 1947 . What is $C$ ?

Therefore, $C=0.0875 \times\left[\frac{\mathbf{0 . 1 7 4 8 9 5}}{\mathbf{0 . 0 8 7 5}}\right]^{\frac{\mathbf{1 0 0}}{\mathbf{1 0}}}$

$$
\mathrm{C}=0.0875 \times 1017.87256
$$

\section{$C=89.063849$ crore}

\section{Mathematical Results-I:}

From case-I, case-II, case-III, case-IV, case-V and case-VI, we can write the above mathematical results in tabular form of the following:

Table-I

\begin{tabular}{|c|c|c|c|c|c|}
\hline $\begin{array}{l}\text { MM } \\
\text { period } \\
\text { 't' } \\
\text { (years) }\end{array}$ & $\begin{array}{c}\text { MEV constant } \\
\text { 'K' } \\
0.20\end{array}$ & 0.40 & 0.60 & 0.80 & 0.9988 \\
\hline 10 & 0.105 & 0.1225 & 0.14 & 0.1575 & 0.174895 \\
\hline 20 & 0.126 & 0.1715 & 0.224 & 0.2835 & 0.34958013 \\
\hline 30 & 0.1512 & 0.2401 & 0.3584 & 0.5103 & 0.69874076 \\
\hline 40 & 0.18144 & 0.33614 & 0.917504 & 0.91854 & 1.39664302 \\
\hline 50 & 0.217728 & 0.470596 & 1.4680064 & 1.653372 & 2.79161006 \\
\hline 60 & 0.2612736 & 0.6588344 & 2.3488102 & 2.6453952 & 5.5798702 \\
\hline 70 & 0.3135283 & 0.9223682 & 3.7580964 & 4.7617114 & 11.1530445 \\
\hline 80 & 0.3762339 & 1.2913154 & 6.0129542 & 8.5710804 & 22.2927054 \\
\hline 90 & 0.4514808 & 1.8078416 & 9.6207267 & 15.4279448 & 44.5586595 \\
\hline 100 & 0.5417769 & 2.5309782 & 15.3931628 & 27.7703006 & 89.063849 \\
\hline $\begin{array}{c}\text { Average } \\
=\frac{\sum \square}{\square}\end{array}$ & 0.27256615 & 0.85521738 & 4.02416607 & 6.26996444 & 17.8059597 \\
\hline
\end{tabular}

Statistical Study Of Corruption For Model-I

\begin{tabular}{|c|c|c|c|c|c|}
\hline $\begin{array}{c}\text { Data } \\
\mathrm{X}\end{array}$ & $\begin{array}{c}\text { Sample-I } \\
\mathrm{f}\end{array}$ & $\mathrm{f} . \mathrm{x}$ & $\mathrm{D}=(\mathrm{x}-\mathrm{X})$ & $D^{2}$ & ${\text { f. } D^{2}}^{2}$ \\
\hline 10 & 0.139979 & 1.39979 & -78 & 6084 & 851.632236 \\
\hline 20 & 0.23091603 & 4.6183206 & -68 & 4642 & 1071.91221 \\
\hline 30 & 0.39174815 & 11.7524445 & -58 & 3364 & 1317.84078 \\
\hline 40 & 0.7500534 & 30.002136 & -48 & 2304 & 1728.12303 \\
\hline 50 & 1.32026249 & 66.0131245 & -38 & 1444 & 1906.45904 \\
\hline 60 & 2.29883672 & 137.930203 & -28 & 784 & 1802.28799 \\
\hline 70 & 4.18174976 & 292.722483 & -18 & 324 & 1354.88692 \\
\hline 80 & 7.70885786 & 616.708629 & -8 & 64 & 493.366903 \\
\hline 90 & 14.3733307 & 1293.59976 & 2 & 4 & 57.4933228 \\
\hline 100 & 27.0600136 & 2706.00136 & 12 & 144 & 3896.64196 \\
\hline & $\mathrm{N}=\sum f=58.456$ & $\sum f . x=5160.74825$ & & & $\sum f . D^{2}$ \\
\hline
\end{tabular}

$\mathbf{X}=$ Mean $=\frac{\sum f \cdot x}{\mathrm{~N}}=\frac{5160.74825}{58.456}=88.2843207 \approx 88$ 
Therefore, Mean $=\mathbf{8 8}$

We know that the formula for Standard Deviation is as follows:

Therefore, S. D. $=\sigma=\sqrt{\frac{\sum f D^{2}}{N}}=\sqrt{\frac{14480.6444}{58.456}}=\sqrt{247.718701}$

S. D. $=\sigma=15.739082$

Therefore the standard deviation of corruption in India with related period is 15.74.

Statistical Graph Of Model-I:

\begin{tabular}{|c|c|}
\hline MEV Constant ' $\mathbf{K}$ ' & Corruption ' $\mathbf{C}$ ' (crore) \\
\hline 0 & 0.0875 \\
\hline 0.20 & 0.2725662 \\
\hline 0.40 & 0.8552174 \\
\hline 0.60 & 4.0241661 \\
\hline 0.80 & 6.2699644 \\
\hline 0.9988 & 17.8059597 \\
\hline
\end{tabular}

The Graph Between MEV Constant ' $K$ ' And Corruption ' $C$ '

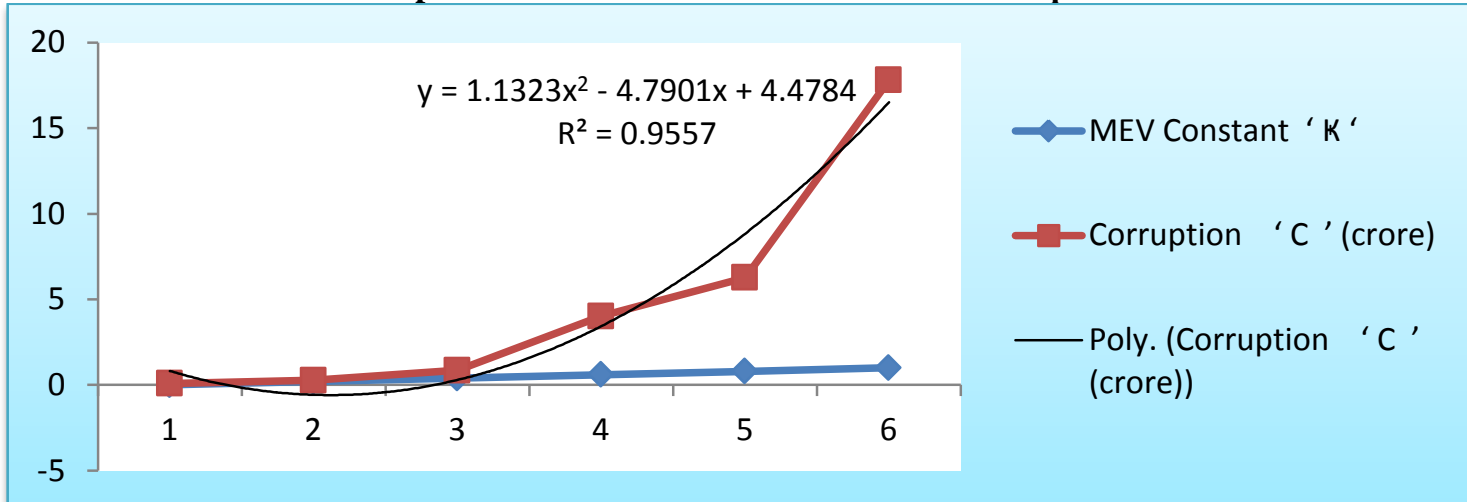

We have observed that when we assumed value $0.25 \%, \mathrm{C}(0)=0.0875$ crore.

First stage corruption: when $0<K \leq 0.40, \mathrm{C}=0.8552174$ crore.

Medium stage corruption: when $0.40<K \leq 0.80, \mathrm{C}=5.414747$ crore.

Final stage corruption: when $0.80<K<1, C=11.5359953$ crore.

\subsection{Mathematical Growth of Development Model except Corruption:}

We assume that corruption was $0.25 \%$ of total population 35 crore that is 0.0875 crore on 15 August, 1957. Then $D(0)=0.1750$ crore (in rupees) when $C=0$ and we take MM Period $t=10$ years. Therefore $D(C)$ depends on MEV constant $\mathrm{K}$. We know that Mathematical E-virus constant model with related corruption, we have

Therefore, $K=\left[\frac{D(C)}{D(0)}\right] \overline{\mathbf{c}}-1,-1<K<1$

Putting this value in the MCD Model, we get

Therefore, $D(C)=D(0)[1+K]^{C}$

$$
D(C)=0.1750 \times\left[\frac{D(C)}{D(0)}\right]^{C}
$$

When $K=0, C=0$, from (vi), $D(C)=D(0)=0.1750$ crore

When $K=0.20, C=0.2725662$ crore then $D(C)=0.2100$ from (vi), we have

Therefore, $D(C)=0.1750 \times\left[\frac{0.2100}{0.1750}\right]^{0.2725662}$

$$
D(C)=0.1750 \times 1.050950
$$

$$
D(C)=0.1839163 \text { crore }
$$

When $K=0.40, C=0.8552174$ crore, then $D(C)=0.2450$ from (vi), we have

Therefore, $\mathrm{D}(\mathrm{C})=0.1750 \times\left[\frac{0.2450}{0.1750}\right]^{0.8552174}$

$$
D(C)=0.1750 \times 1.3334331223
$$

$$
D(C)=0.2333507964 \text { crore }
$$

When $K=0.60, C=4.0241661$ crore, then $D(C)=0.2800$ from (vi), we have

Therefore, $D(C)=0.1750 \times\left[\frac{0.2800}{0.1750}\right]^{4.0241661}$

$$
\begin{array}{r}
D(C)=0.1750 \times 6.62846114 \\
D(C)=1.1599807 \text { crore }
\end{array}
$$


When $K=0.80, C=6.2699644$ crore, then $D(C)=0.3150$ from (vi), we have

Therefore, $D(C)=0.1750 \times\left[\frac{0.3150}{0.1750}\right]^{6.2699644}$

$$
D(C)=0.1750 \times 39.861122 \quad D(C)=6.9756964 \text { crore }
$$

When $K=0.9988, C=17.8059597$ crore, then $D(C)=0.34979$ from (vi), we have Therefore, $D(C)=0.1750 \times\left[\frac{0.34979}{0.1750}\right]^{17.8059597}$

$$
D(C)=0.1750 \times 226718.3962154
$$

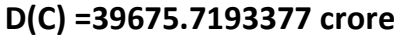

Now we have observed that when we assumed value $0.25 \%, D(0)=0.1750$ crore. Then First stage corruption:

When $0<K \leq 0.40, C=1.1277836$ crore then

$$
D(C)=0.4172671 \text { crore }
$$

Medium stage corruption:

When $0.40<K \leq 0.80, C=10.2941305$ crore

Final stage corruption:

$$
D(C)=74.2756617 \text { crore }
$$

When $0.80<K<1, C=17.8059597$ crore

Mathematical Result-II:

$D(C)=39675.7193377$ crore

The mathematical result of the above data can be written in the following table. Also, we have observed that the relation between MEV Constant, Corruption (in population size) and Development (in rupees)

Table-II

\begin{tabular}{|c|c|c|}
\hline MEV Constant ' $\mathbf{K}$ ' & Corruption 'C ' (crore) & Development 'D' (crore) \\
\hline 0 & 0.0875 & 0.1750 \\
\hline 0.20 & 0.2725662 & 0.1839163 \\
\hline 0.40 & 0.8552174 & 0.2333508 \\
\hline 0.60 & 4.0241661 & 1.1599807 \\
\hline 0.80 & 6.2699644 & 6.9756964 \\
\hline 0.9988 & 17.8059597 & 39675.7193377 \\
\hline Regression Square $\left(\mathbf{R}^{2}\right)$ & $\mathbf{0 . 9 8 5}$ & $\mathbf{0 . 9 9 4}$ \\
\hline
\end{tabular}

The graphs of Table-Il are as follows:

Graph-II: The Graph between MEV Constant and Corruption

\section{Corruption ' C' (crore)}

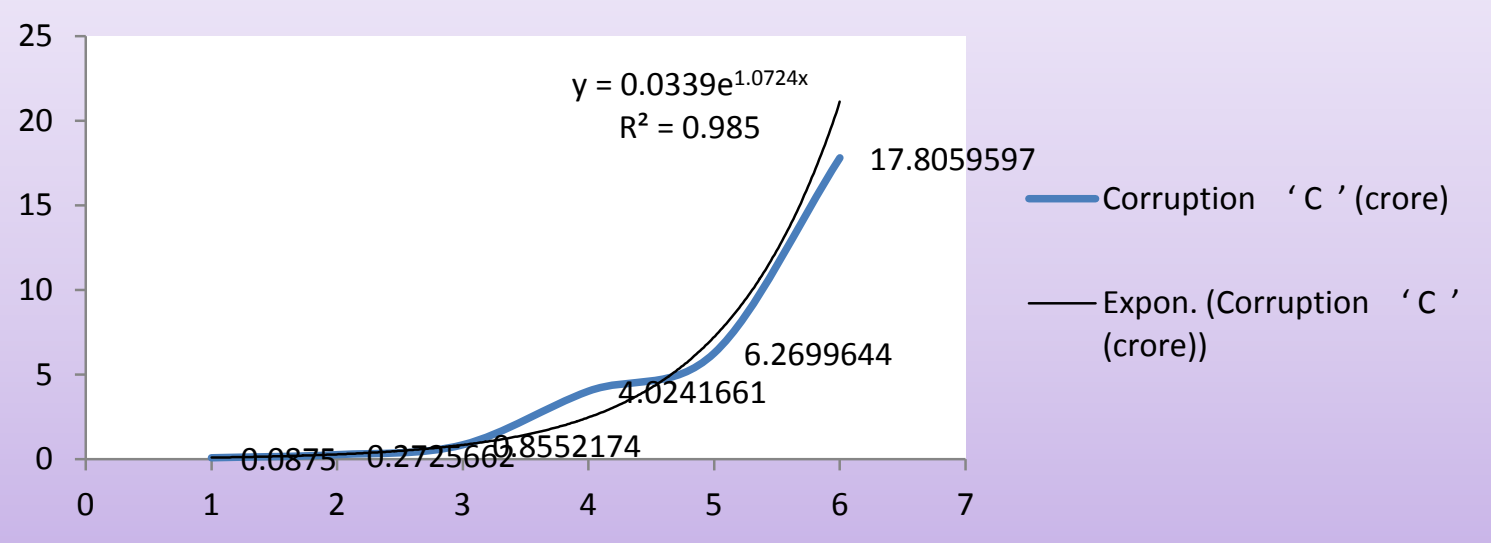




\section{Graph-III: The Graph between Corruption and Development}

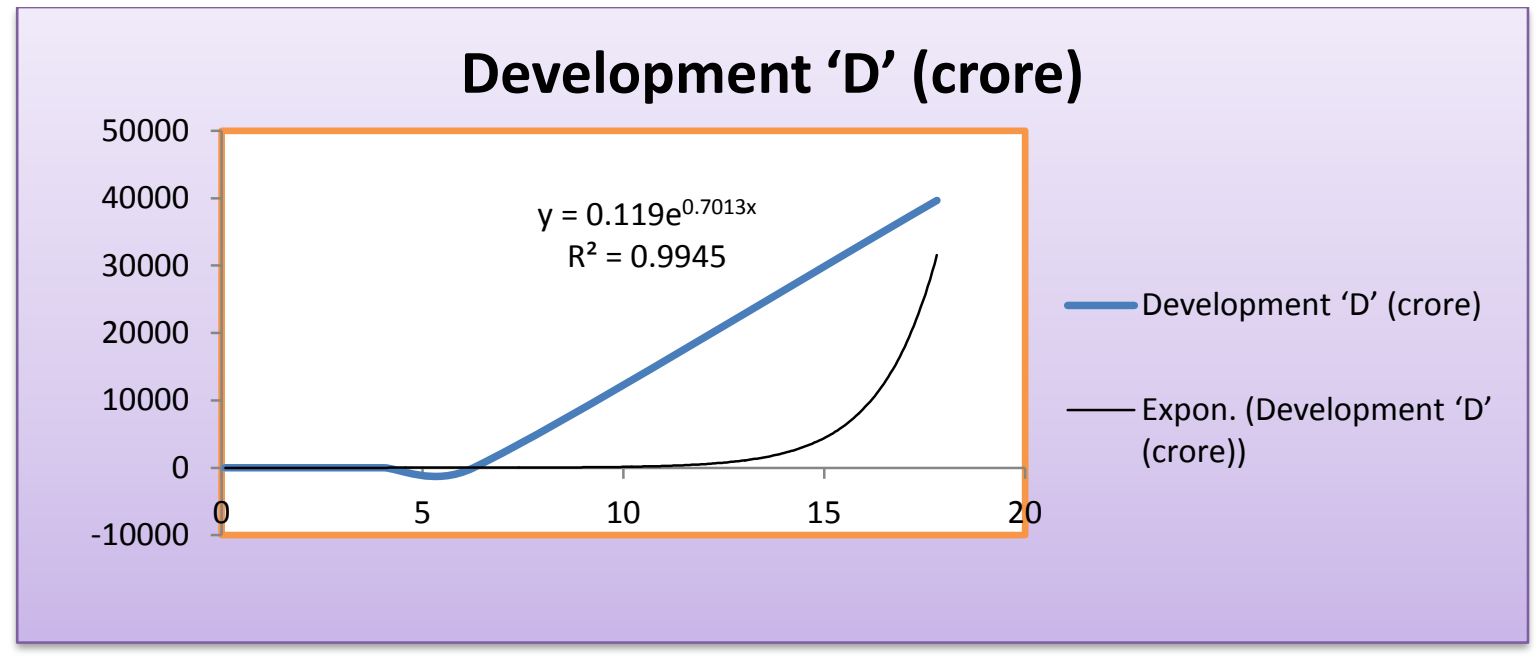

This shows that the Mathematical Corruption Model is statistically fit for exponential, polynomial and power form. Also it is liner. Therefore it is valid for the above illustrations.

VI. Conclusion

We have observed and it concluded that the mathematical results are as follows:

First stage corruption:

When $0<K \leq 0.40 \quad C=1.1277836$ crore $\quad D(C)=0.4172670789$ crore

Medium stage corruption:

When $0.40<K \leq 0.80$

$$
C=1.1277836 \text { crore }
$$

$$
\text { C }=10.2941305 \text { crore }
$$

$$
D(C)=74.275661664 \text { crore }
$$

$$
C=17.8059597 \text { crore } \quad D(C)=39675.719337696 \text { crore }
$$

\section{$\mathrm{C}=17.8059597$ crore}

Therefore the Mathematical Corruption Model is valid for the above two illustrations and the S.D. means the inflation, it is 15.74. Also we have observed that 'the corruption and inflation are related to each other'. When corruption increases then inflation increases and vice versa ${ }^{[19]}$. Also the regression square $\left(R^{2}\right)$ is less than 1. Therefore the mathematical corruption model is fit statistically.

\section{References}

[1]. Andriole SJ (1983) Handbook of Problem Solving: An Analytic Methodology Princeton, NJ: Petrocelli Books.

[2]. Blum, W. Niss, M.(1991). Applied Mathematical Problem Solving, Modeling, Applications and links to other subjects- state, trends and issues in mathematics instruction. In: Educational studies in Mathematics, 22(1), 37-68.

[3]. BhaskarDasgupta, Applied Mathematical Methods published by Darling Kindersley (India) Pvt. Ltd. Delhi.

[4]. Bender EA (1978) An Introduction to Mathematical Modeling New York: John Wiley andSons.

[5]. Daniel A. Murray, Introductory Course in Differential equations, Orient Longman ltd.Harlow and London (1993).

[6]. De Lange, J. (1996). Real Problems with Real world Mathematics. In L. Alsina \& al.(Eds.) proceeding of the 8th Int. Congress on Math.1 Education (pp. 83-110). Seville: Thales.

[7]. Mauro, Paolo (1995). 'Corruption and Growth'. Quarterly Journal of Economics 110:681-712.

[8]. SayajiRastumWaykar (2013), Mathematical modelling: A study of corruption in the Society, IJSER, Vol. 4, Issue 7, pp 2303-2318 (USA).

[9]. SayajiRastumWaykar (2013), Mathematical modelling: A way of a life, IJSER, Vol. 5, Issue 5, May- 2013 edition (USA).

[10]. Schoenfeld A. H. (1994). Mathematical Thinking and Problem Solving. Hillsdale: Erlbaum

[11]. Stillman G (2002) Assessing Higher order Mathematical Thinking through ApplicationsPh.D Thesis) Brisbane: The university of Queensland.

[12]. Shleifer, Andrei and Vishny, R. W. 1993. 'Corruption' Quarterly Journal of Economics 108:599-617

[13]. SayajiRastumWaykar (2013), Mathematical modelling: A comparatively mathematical Study model base between corruption and development, IOSR Journal of Mathematics, Vol. 6, Issue 2, pp 54-62.

[14]. SayajiRastumWaykar (2014), Mathematical modelling: A study of corruption in various fields of the society, IOSR Journal of Mathematics, Vol. 10, Issue 1, Ver. I, PP 29-38.

[15]. Treilibs, V; Burkhardt, H; and Low, 1 (1980). Formulation processes in Mathematical Modelling; Nottingham: shell centre for Mathematical Education.

[16]. Transparency International (2005). 'India Corruption Study 2005' Published by Transparency International India LajpatBhawan, Lajpat Nagar IV, New Delhi

[17]. Treisman, D. (2000). 'The Causes of Corruption: A Cross-National Study'. Journal ofPublic Economics, 76(3): 399-458

[18]. Verschaffel, L.; Greer, B.; De Corte, E. (2000). Making sense of world Problems. Lisse: Swets\&Zeitlinger.

[19]. Hasim Akca, Ahmet Yilmaz Ata and Coskun Karaca (2012), Inflation and Corruption Relationship: Evidence from Panel Data in Developed and Developing Countries, International Journal of Economics and Financial Issues, Vol. 2, No. 3, pp.281-295. 